acologists but also clinicians, chemists, biochemists, physicists, bacteriologists, pathologists and other biologists, working in both university and industrial laboratories, have contributed to these advances, but their work is scattered throughout numerous journals. The new journal will bring together work, in all these fields, which is concerned with the effects of chemical substances on animals, living tissues and their chemical systems. It will publish original work in all branches of pharmacology and experimental chemotherapy, including the biochemical and pathological aspects of this subject. Provision will also be made for shorter communications and for brief notes on technique.

The editorial board of the new journal is : Prof. J. H. Gaddum, professor of pharmacology, University of Edinburgh (chairman); Prof. J. H. Burn, professor of pharmacology, University of Oxford ; Dr. F. Hawking, of the research staff of the Medical Research Council; Dr. H. R. Ing, reader in pharmacological chemistry, University of Oxford; Dr. N. Mutch, physician to Guy's Hospital; Dr. C. M. Scott, director of the Pharmacological Laboratories, Imperial Chemical Industries, Ltd. ; Prof. F. R. Winton, professor of pharmacology, University of London; and the editor of the British Medical Journal. Papers intended for publication should be sent to Dr. H. R. Ing, Department of Pharmacology, Oxford. Each volume will consist of four quarterly parts and will cost $25 s$. Subscriptions, payable in advance, should be sent to the British Medical Association, B.M.A. House, Tavistock Square, London, W.C.1.

\section{Organisation of Research in the United States}

Av open letter signed by the members of a committee supporting the Bush Report has been addressed to President Truman on pending legislation for Federal aid to science (Science, 102, 545, 1945). The letter indicates that the committee favours the Magnuson Bill and is opposed to the Kilgore Bill. It believes that the main responsibility for the programme should be placed in the hands of a national science or research board composed of laymen and scientific men appointed by the President solely on the basis of interest in, and capacity to promote, scientific research and education. The committee is emphatically opposed to the subordination of the board to a single director appointed by the President, as is done in the Kilgore Bill. The board should be responsible for the appointment of the chief administrative officer of the foundation and no ex officio members of other Government agencies should serve as active members of the board. The committee does not think that the board should undertake to control or co-ordinate all Government scientific activity, but that, given high standards and sound practice in scientific education and research, the proliferation of interests and activities, together with a high degree of institutional and individual freedom and respon. sibility, is desirable. It is considered that social sciences should be taken care of by a separate body, and the point of view expressed in this letter is endorsed on behalf of the combined executive committees of the Union of American Biological Societies and of the American Biological Society, in a note signed by Prof. Robert Chambers and Prof. J. S. Nicholas, the respective presidents, which indicate that, as biologists, they are keenly interested in realizing the contemplated plans to include the biological sciences in a division of basic science separate from medical research and public welfare.

\section{Visual Education in China}

THE University of Nanking is contributing vitally to educational development in China in its MotionPicture Department, now ten years old. The Department has provided a two-year college course in motion-picture and radio, now to be extended to a full four-year course-a most important step which incidentally has no counterpart in Great Britain. Graduates spread all over China, and some have been sent to study cinematography in the United States. The Department issues a monthly periodical, Film and Radio, containing both technical and general information and illustrations. It has provided an extensive programme of motion-picture and filmstrip shows for war information, general education and instruction. Films from British, American and Canadian sources are used, but an increasing number are produced in China.

The figures are impressive. At Cheng-tu (to which the University evacuated) fortnightly open-air shows averaged audiences of 10,000 with a peak of 29,000 . In 1944 , a total of 826 shows were organised, the aggregate audiences being more than 800,000 . Nearly 6,000 film-strips were shown to more than a million people during the first four months of 1945 . Leading professors are contributing to a production programme of two educational film-strips a month. The film is now part of the communal and university life, and is extensively used by professors and students. Many organisations and war factories in the Cheng-tu area have benefited by the work of the Department. In the University itself, a projection room, dark room and studio are provided for the use of staff and students. It has planned to extend this pioneer work of administration, training and research to five other universities.

\section{Animal Population Research in India}

THE problems of animal population and migration have aroused increasing interest of recent years, and in stressing the need of a central institute in India, Major Roonwal, assistant superintendent of the Zoological Survey, will have the sympathy of most naturalists (Sci. and Culture, 11, 10 ; 1945-46). Attention is directed to similar work in other countries, especially in the United States, with its Fish and Wild Life Service, and the U.S.S.R., where very extensive studies have been made on animal populations, those on mammals and insects being the most extensive. In the U.S.S.R. there is a tendency to seek for causes of fluctuation in climate, and experimental work on the American model is not much in vogue. British research on the subject has been largely centred at the Bureau of Animal Population, Oxford, under the direction of Mr. C. Elton. Its practical applications are of the highest value to agriculture, fisheries and public health. Plagues of insects and mammals, especially rodents, are familiar to agriculturists the world over, and even in normal times their depredations are enormous. Fisheries fluctuate from year to year, and up to now little is known of the factors which govern the natural periodic rhythms of fish populations.

Finally, mammals play an important part in the transmission of various diseases in India, one of the best-known examples being the relationship between rats and bubonic plague, and although there is some indication of short population rhythms in India, there have been no extensive studies such as those being carried on in the U.S.S.R. on the fluctuations of mouse-like rodents associated with plague. The 